TOMASZ KIZWALTER

Instytut Historyczny

Uniwersytetu Warszawskiego

\title{
POZAGROBOWY ŻYWOT RZECZYPOSPOLITEJ
}

Rocznicowe narracje nie pozostawiają tu cienia wątpliwości: w 2018 r. mija 100 lat od odzyskania - a nie uzyskania - przez Polskę niepodległości. Trudno zresztą, aby podchodzono do tego inaczej, zważywszy na dobrze znane społeczne funkcje rocznic oraz powszechną, ogólnoświatową skłonność do tworzenia możliwie długich i możliwie jednoznacznych narodowo-państwowych genealogii. Trzeba też od razu powiedzieć, że istnieją poważne argumenty na rzecz tezy o przynajmniej częściowej ciągłości między I a II Rzecząpospolitą - nie jest to tylko kwestia potocznego przeświadczenia, że Polacy od niepamiętnych czasów mają państwo i że jest to $\mathrm{w}$ istocie to samo państwo, choć na jakiś czas może zostać zniszczone lub ulec zepsuciu. Tego rodzaju wyobrażenia wpływają na dyskurs akademicki, lecz w żadnym razie nie stanowią jedynego źródła tezy o ciągłości.

Państwo, którego materialnie uchwytna egzystencja zakończyła się w 1795 r., miało długi żywot pośmiertny. O tym pozagrobowym życiu świadczyło w dziewiętnastowiecznej Europie między innymi zaliczanie Polaków do „narodów historycznych”, czyli takich, które mogą wylegitymować się tradycją państwową ${ }^{1}$. Wynikały z tego istotne konsekwencje, bo choć opinie o Polakach bywały wówczas, od Francji po Rosję, niezbyt pochlebne, to uznawano ich - mimo rozpowszechnionego przekonania o anarchicznym usposobieniu polskiej szlachty - za uprawnionych do udziału w polityce. W Polsce mocno ugruntował się pogląd, że był to

1 Zob. J. Breuilly, Approaches to Nationalism, w: Formen des nationalen Bewußtseins im Lichte zeitgenössischer Nationalismustheorien, red. E. Schmidt-Hartmann, München 1994, s. 18 . 
udział w roli ofiary, cierpiącej nie tylko z powodu brutalności zaborców, ale i hipokryzji domniemanych sojuszników, takich jak Francja i Wielka Brytania. Rozpamiętywanie krzywd można by skwitować dość banalną uwagą, że taka po prostu była i w znacznej mierze jest polityka. Warto jednak wskazać, że jeśli Polacy byli ofiarą dziewiętnastowiecznej polityki, to Ukraińcom i Słowakom nie przysługiwał nawet taki status. Ich przeważnie w ogóle nie dostrzegano albo - z biegiem czasu - nie chciano dostrzec. Nie uznawano ich ani za podmioty polityki, ani za jej przedmioty. W najlepszym razie skazywani byli, jako „narody niehistoryczne”, na cierpliwe oczekiwanie, aż okażą się godni politycznej partycypacji; częściej jednak sądzono, że ich wspólnota ma charakter fikcyjny i stanowi wynik jakichś podejrzanych zabiegów (tak jak Ukraińców miał wymyślić gubernator Franz Stadion). Jakiekolwiek byłyby zatem rzeczywiste lub domniemane krzywdy, jakich doświadczał polski ruch narodowy, to sam fakt politycznej obecności miał niebagatelne znaczenie. „Sprawa polska” mogła być rozmaicie oceniana - sądzono przecież często, że spełnienie polskich oczekiwań jest nierealne i/lub niepożądane - ale nigdy nie zniknęła zupełnie z polityki europejskiej.

Zewnętrzni obserwatorzy nie mówiliby o „historyczności” Polaków, gdyby zabrakło polskiego poczucia związku z Rzecząpospolitą, która choć złożona do grobu, nie wydawała się całkiem martwa. Znamy oczywiście świadectwa porozbiorowej depresji wrażliwych twórców, opłakujących śmierć ojczyzny; znamy też znacznie liczniejsze przejawy pragmatycznego - a czasem cynicznego (Stanisław Szczęsny Potocki: „Ja już jestem Rosjaninem na zawsze") - dostosowywania się do zmienionej sytuacji politycznej ${ }^{2}$. Ani trauma, ani życiowy pragmatyzm nie mogą jednak przesłonić pośmiertnej obecności Rzeczypospolitej. Państwo to pozostawiło po sobie kulturę politycznej aktywności, po rozbiorach odwołującą się do imaginarium, które konstruowano, czerpiąc materiał ze szczęśliwszej przeszłości. Kultura aktywności stanowiła podstawę kształtowania się elit o daleko sięgających ambicjach. Aspiracje trzeba było zawsze konfrontować z politycznymi realiami, najczęściej niesprzyjającymi śmiałym przedsięwzięciom, a różne środowiska i generacje rozmaicie odnosiły się do zasady Realpolitik. Jeśli jednak okoliczności uznawano - słusznie czy niesłusznie, z dzisiejszej perspektywy - za przychylne, to pojawiała się myśl o odbudowie własnego państwa. Własnego państwa, czyli Rzeczypospolitej.

Takie twierdzenie jest oczywiście upraszczającym uogólnieniem. Po pierwsze, już w samych początkach okresu porozbiorowego

2 J. Czubaty, Zasada „dwóch sumień”. Normy postępowania i granice kompromisu politycznego Polaków w sytuacjach wyboru (1795-1815), Warszawa 2005, s. 105-295. 
„Rzeczpospolita” nie była pojęciem jednoznacznym. Po drugie, z upływem czasu narastała skłonność do modyfikowania, czasem zaś odrzucania wzorców, które wywodzono z przeszłości.

Wyjściowa niejasność pojęcia „Rzeczypospolitej” wiąże się przede wszystkim ze zmianami ustrojowymi, których doświadczała ona w ostatnich latach swego materialnego istnienia. Można rzecz jasna przyjąć, że wkrótce po trzecim rozbiorze wśród ludzi myślących o wskrzeszeniu państwa - a zatem przeciwstawieniu się zaborcom - dominowało przywiązanie do umiarkowanie reformatorskiego wzorca trzeciomajowego. Dlaczego jednak mielibyśmy odrzucać pogląd, że w kręgu tych, którzy chcieliby odzyskania państwowości, znajdowała się również część przeciwników reform? Patriotyzm typu barskiego, choć przesłonięty przez konflikt między walczącymi w obronie państwa reformatorami a opcją targowicko-grodzieńską, nie zniknął przecież bez śladu. Byli też, choć nieliczni, patrioci, których reformatorski zapał prowadził poza standardy Ustawy Rządowej.

Tego rodzaju różnice nieuchronnie pogłębiały się w nadchodzących latach. Po wejściu na ziemie polskie wojsk napoleońskich narzucono Polakom system ustrojowy różniący się znacznie od wszystkiego, z czym mieli do czynienia w Rzeczypospolitej. Większości rodzimej klasy politycznej nie podobał się, ale akceptowano go, czekając na odtworzenie „prawdziwej Polski", które wyobrażano sobie na ogół jako powrót do Konstytucji 3 maja. Jeszcze podczas powstania listopadowego Maurycy Mochnacki, uznawany przez ziemiański establishment za niebezpiecznego radykała, przekonywał, że polska „rewolucja” ma prowadzić do „restauracji”: "Nowej nie improwizujemy Polski, ale z grobu wywołujemy Ojczyznę"3. W tym czasie coraz częściej dochodzono jednak do wniosków, które nie mieściłyby się w głowie przedrozbiorowej szlachcie. Sam Mochnacki, pełen podziwu dla trzeciomajowych pryncypiów ustrojowych, wkrótce po powstaniu, zwróciwszy uwagę na postanowienia prawa o miastach z kwietnia 1791 r., dopatrzył się w nim idei uszlachcenia całego społeczeństwa $^{4}$. Ta śmiała interpretacja nie przyniosła wtedy autorowi popularności, ale skłóceni z nim emigracyjni demokraci w centrum swych deklaracji programowych również umieszczali kwestię stosunków między „szlachtą" a "ludem”.

W emigracyjnych polemikach ideowych $\mathrm{z}$ lat trzydziestych i czterdziestych widać ścieranie się dwóch tendencji. $Z$ jednej strony mamy

${ }^{3}$ M. Mochnacki, Restauracja i rewolucja, w: idem, Pisma wybrane, wstęp J. Szacki, wybór i przypisy R. Janiec, Warszawa 1957, s. 279.

${ }^{4}$ M. Mochnacki, O rewolucji społecznej w Polszcze, w: idem, Pisma wybrane, s. 289-291. 
zatem chęć zapewnienia narodowego przywództwa „szlachcie”, z drugiej - pragnienie społecznej demokratyzacji. Nie jest całkiem jasne, kogo zaliczano w tym przypadku do „szlachty”. Termin ten występował wtedy w kilku znaczeniach - wydaje się, że w kontekście debat o przywództwie chodziło zarówno o ziemiaństwo, jak i ludzi pochodzących z rodzin szlacheckich $^{5}$. Nie sądzę, aby dokładna identyfikacja społeczna była tu szczególnie istotna. Pisząc o „szlachcie”, miano na myśli zbiorowość reprezentującą tradycję Rzeczypospolitej - dzięki posiadaniu majątku ziemskiego, pochodzeniu rodzinnemu, przede wszystkim jednak z racji związków kulturowych. Aż do upadku powstania styczniowego „szlachta” odgrywała kluczową rolę w narodowym dyskursie i tylko na jego zupełnym marginesie - w tekstach Gromad Ludu Polskiego i ks. Piotra Ściegiennego - pojawiała się idea obalenia szlacheckiej dominacji. Działacze i publicyści głównego nurtu orientacji demokratycznej, czyli członkowie Towarzystwa Demokratycznego Polskiego, starali się jak mogli pogodzić ze sobą koncepcję emancypacji „ludu” i przekonanie, że usytuowana wysoko w społecznej hierarchii „szlachta” stanowi nieodzowny składnik narodowej egzystencji ${ }^{6}$.

Sytuacja zmieniła się po powstaniu styczniowym. Najważniejszym obok reformy stosunków wiejskich - następstwem wydarzeń lat 18631864 była zasadnicza rewizja polskiego imaginarium politycznego. Klęska powstania, rodząca poczucie bezużyteczności czy nawet szkodliwości dotychczasowych wzorców odczuwania, myślenia i działania, sprzęgła się ze zmianami społecznymi. Po reformie agrarnej i rosyjskich represjach społeczna pozycja ziemiaństwa osłabła; nie poprawił jej nadchodzący kryzys gospodarki rolnej. Nie mogło to pozostać bez wpływu na sferę idei i zbiorowych wyobrażeń: minęły czasy Adama Jerzego Czartoryskiego i Andrzeja Zamoyskiego. Z inteligenckich elit, które po powstaniu wysunęły się na plan pierwszy jako siła opiniotwórcza, zaczęła wychodzić ostra krytyka tego, co uznawano za szkodliwą spuściznę Rzeczypospolitej. Nowe orientacje ideowe - od stańczyków i warszawskich pozytywistów po nacjonalistów i socjalistów - konstruowały swe programy, podkreślając, z rozmaitym rzecz jasna naciskiem, że należy odrzucić błędy przeszłości.

Jak daleko sięgała owa rewizja i jakie miała znaczenie? Cudzoziemcy jeszcze długo przejawiali skłonność do dostrzegania w Polsce „szlachty”. Obserwacje takie były często zabarwione niechęcią i lekceważeniem: Polak okazywał się „,szlachcicem”, czyli z jednej strony kimś anachronicznym,

${ }^{5}$ Zob. J. Jedlicki, Klejnot i bariery społeczne. Przeobrażenia szlachectwa polskiego w schytkowym okresie feudalizmu, Warszawa 1968, s. 247-251.

6 T. Kizwalter, O nowoczesności narodu. Przypadek polski, Warszawa 1999, s. 230-258. 
z drugiej - reprezentującym kulturę wywyższania się i ucisku (,szlachcic” bywał też „rycerzem wolności”, co jednak zdarzało się rzadziej). To negatywna strona polskiej „historyczności”, pozwalającej Polakom być zauważanymi w Europie jako podmiot polityczny. „Historyczność”, która w pierwszej połowie XIX w. stanowiła dla polskich elit politycznych istotny atut, $\mathrm{z}$ biegiem czasu przekształcała się w obciążenie. Odczuwano to nieraz $\mathrm{w}$ relacjach $\mathrm{z}$ cudzoziemcami, ale $\mathrm{z}$ prawdziwie poważnym problemem miano do czynienia w stosunkach wewnętrznych.

$\mathrm{Z}$ badań nad kształtowaniem się narodów od dawna wyprowadza się słuszny i obecnie dość oczywisty wniosek, że w procesach narodowotwórczych kluczową rolę odgrywała demokratyzacja społeczna, z którą ściśle wiązało się dowartościowywanie kulturowej „rodzimości”. Miroslav Hroch pokazał, że w niektórych przypadkach przemiany tego rodzaju daje się ująć w stosunkowo prosty schemat interpretacyjny: od elitarnego zainteresowania kulturą do masowego ruchu politycznego ${ }^{7}$. Schemat Hrocha, cieszący się wielką popularnością, odnosi się jednak do narodów „niehistorycznych”. Sprawa komplikuje się, gdy w grę zaczyna wchodzić czynnik „historyczności”.

W przypadku polskim widać narastającą presję przekonań demokratycznych, które po powstaniu styczniowym zaczęły przytłumiać historycznie ukształtowane wyobrażenia społecznych podziałów i hierarchii. Józef Szujski chciał jeszcze zachowania „warstwy historycznej”, lecz Aleksander Świętochowski piętnował ,jałowy grunt szlacheckiej tradycji”, a Jan Ludwik Popławski nie sądził już, aby należało nazywać narodem „tę nieliczną garstkę spadkobierców przeszłości, warstwę, która pływa jak pozłota na rosole"8. Popławski, sugerujący w 1886 r. na łamach warszawskiego „Głosu” możliwość przeciwstawienia „narodowi szlacheckiemu” „narodu chłopskiego”, dotarł w tym momencie do punktu krytycznego - i cofnął się. Wkrótce złagodził swoje poglądy, uznając wartość historycznych wyznaczników polskości ${ }^{9}$.

Ewolucję poglądów Popławskiego - która sama w sobie nie miała przecież żadnego fundamentalnego znaczenia - można uznać za sygnał

${ }^{7}$ M. Hroch, Social Preconditions of National Revival in Europe. A Comparative Analysis of the Social Composition of Patriotic Groups among the Smaller European Nations, Cambridge 1985.

8 J. Szujski, Odpowiedź „Dziennikowi Poznańskiemu” na recenzję broszury „Kilka prawd z dziejów naszych", w: Stańczycy. Antologia myśli społecznej i politycznej konserwatystów krakowskich, wstęp i oprac. M. Król, Warszawa 1985, s. 92-93; A. Świętochowski, Praca u podstaw (Ogólne jej pojęcie), w: J. Rudzki, Świętochowski, Warszawa 1963, s. 117; T. Kulak, Jan Ludwik Popławski 1854-1908. Biografia polityczna, t. 2, Wrocław 1989, s. 450.

${ }^{9}$ T. Kizwalter, op. cit., s. 276-288. 
istotnego przesilenia. Odwołująca się do idei społecznej demokratyzacji krytyka Rzeczypospolitej i spadku po niej dochodziła w pewnym momencie do myśli o radykalnym odcięciu się od przeszłości. Myśl taka, pojawiwszy się, nie zyskała jednak szerszego poparcia. Kiedy Popławski przedstawiał swe refleksje o dwóch narodach, czytelnicy entuzjazmowali się lekturą historycznych powieści Henryka Sienkiewicza. Nacjonaliści i socjaliści, zaczynający na przełomie wieków kształtować polskie życie polityczne, zwracali się do mas z projektami społecznymi, które znacznie różniły się między sobą, ale miały jedną nieuniknioną cechę wspólną: z naciskiem odrzucano w nich podziały i hierarchie rodem z Rzeczypospolitej. Tylko marksiści z kręgu Socjaldemokracji Królestwa Polskiego/ Socjaldemokracji Królestwa Polskiego i Litwy przedstawiali wszakże program odrzucający ideę polskiej państwowości; inni budowę własnego państwa uznawali za nadrzędny cel polskich dążeń politycznych. I okazywało się, że wizję przyszłego państwa, kreśloną wraz z projektami społecznej demokratyzacji, trudno oderwać od tradycji Rzeczypospolitej.

Trzeba wyjaśnić, co w tym przypadku oznaczała taka tradycja. Wydawać by się przecież mogło oczywiste, że nie obejmowała już wzorców społecznych takich jak idea szlachectwa i zasada przyrodzonej wyższości szlachty nad chłopstwem. Istotnie, na plan pierwszy wysuwała się tu inna część spadku po Rzeczypospolitej: wyobrażenia terytorialne. Rozwój „młodych”, „niehistorycznych” ruchów narodowych sprawił co prawda, że zaczęto zastanawiać się nad rozwiązaniami politycznymi, które w jakiejś mierze zaspokajałyby ukraińskie czy też litewskie aspiracje polityczne, ale dla przytłaczającej większości członków polskich „warstw oświeconych” terytorium Polski wyznaczały przedrozbiorowe granice Rzeczypospolitej (mniej istotne było, jak dobrze znano ich przebieg). Pod tym względem przyszłe państwo w powszechnym odczuciu miało być niewątpliwie kontynuacją Rzeczypospolitej. Nie zmieniały tego przesunięcia graniczne, jakie część działaczy politycznych - głównie z kręgu narodowej demokracji - chciała przeprowadzić na zachodzie i północy, posługując się kryterium etnicznym. Nie oznaczało to wcale rezygnacji z kryterium historycznego, a jedynie jego zgodne $\mathrm{z}$ duchem czasu uzupełnienie. Kiedy jesienią 1918 r. przystąpiono do budowy państwa, kierowano się tym historyczno-etnicznym projektem. Możliwość jego realizacji zależała rzecz jasna przede wszystkim od aktualnego układu sił w Europie, ale ostateczny rezultat polskich działań nawiązywał wyraźnie do terytorialnego kształtu dawnej Rzeczypospolitej.

Co jeszcze pozostało po Rzeczypospolitej nazywanej często „szlachecką"? Demokratyzująca rewizja politycznego imaginarium wyprzedzała przemiany społecznych realiów: niemożność rozwiązania kwestii 
agrarnej stała się poważną barierą rozwojową drugiej z kolei Rzeczypospolitej, a nękający to państwo problem społecznego rozdwojenia, istnienia „dwóch Polsk”, elitarnej i ludowej, przetrwawszy PRL, daje jeszcze o sobie znać w ideologicznych polemikach III Rzeczypospolitej. W $1918 \mathrm{r}$. pośmiertny żywot, który zaczął się w roku 1795, trwał nadal i choć z upływem czasu intensywność tej egzystencji nieuchronnie słabła, to miała ona niebagatelne znaczenie dla losów kraju.

Upraszczając złożoną problematykę, można powiedzieć, że różne elementy spuścizny po przednowoczesnym państwie ścierały się tu z rozmaitymi przejawami nowoczesności. Granice II Rzeczypospolitej nie przebiegałyby tak, jak przebiegały, gdyby nie historycznie uwarunkowane aspiracje polskich elit politycznych, aspiracje te wchodziły zaś w konflikt z dążeniami nowych, „niehistorycznych” ruchów narodowych. Społeczne i kulturowe formy „pańskości”, stale obecne w życiu zbiorowym, zderzały się z nowoczesnym pragnieniem równości. Aby jednak uproszczenie, o którym wspomniałem, nie posuwało się zbyt daleko: świadectwa, mówiące o istotnej roli, jaką w unaradawianiu galicyjskich chłopów odgrywała lektura Trylogii ${ }^{10}$, sygnalizują nam, jak imponującą przyszłość miała przed sobą „wynaleziona tradycja” Rzeczypospolitej. Oczywiście, dzielenie tradycji na ,autentyczne” i „wynalezione” to zabieg dyskusyjny - chociaż istnieją tradycje całkowicie, świadomie i rozmyślnie wymyślone, to nie ma przecież takich, które w pewnym stopniu nie przekształcałyby się dzięki ludzkiej inwencji. Obrazy szlacheckiego państwa, społeczeństwa i kultury pojawiające się w polskim romantyzmie były dziełem nowoczesnych twórców o umysłowości dość już odległej od wzorców sarmackich, a każda kolejna orientacja intelektualna wytwarzała własne wizje. Po tym zastrzeżeniu dotyczącym kulturowej zmienności należy wszakże podkreślić, że spuścizna po Rzeczypospolitej miewała charakter wyraźnie - a czasem dotkliwie - wyczuwalny w społecznej i politycznej praktyce Polski dwudziestowiecznej.

Biogram: Tomasz Kizwalter, prof. dr hab., pracownik Instytutu Historycznego Uniwersytetu Warszawskiego; zainteresowania badawcze: historia idei i wyobrażeń społecznych w XIX i XX w.; kontakt: t.kizwalter@uw.edu.pl.

${ }^{10}$ M. Łuczewski, Odwieczny naród. Polak i katolik w Żmiącej, Torun 2012, s. 307-311. 